\title{
Bridging the Climate and Maritime Legal Regimes: The IMo's 2018 Climate Strategy as an Erga Omnes Obligation
}

\author{
Baine P. Kerr \\ Utrecht Center for Water, Oceans, and Sustainability Law, and Netherlands \\ Institute for the Law of the Sea, Utrecht University School of Law, Utrecht, \\ The Netherlands \\ b.p.kerr@uu.nl
}

\begin{abstract}
Scholarship and practice before the European Court of Justice indicate that international organizations can unilaterally bind themselves under international law. This article evaluates whether the International Maritime Organization did so with its 2018 'Strategy' to reduce greenhouse gas emissions from shipping. After first identifying the source of the IMO's mandate to regulate greenhouse gas emissions from shipping and its treaty obligations to do so, it finds that the Imo has the institutional competence to unilaterally bind itself with respect to its function and purpose of regulating vessel-source pollution. It further finds that the Imo imposed on itself an erga omnes obligation to mitigate climate change in order to meet the Paris Agreement's global warming limitation goals. The article reflects on the implications of these findings for climate law and international law generally.
\end{abstract}

\section{Keywords}

unilateral declarations - erga omnes obligations - international organizations maritime law - emissions from shipping - International Maritime Organization 
International shipping represents a significant share of global greenhouse gas emissions. ${ }^{1}$ The International Maritime Organization, a specialized agency of the United Nations, is charged with developing uniform regulations for pollution from that sector and the thousands of vessels that comprise it. ${ }^{2}$ The IMO began considering whether and how to reduce greenhouse gas emissions in the late 199os. ${ }^{3}$ It first mandated technical and operational energy-efficiency measures in 2011; these were followed in later years by technology-transfer and data-collection measures. ${ }^{4}$ In 2018, the IMO, in a 'Strategy' document, resolved that it would contribute to the Paris Agreement's global warming limitation goals by reducing emissions from international shipping by 50 per cent below 2008 levels by 2050, with a 'vision' of 'phasing them out as soon as possible this century'. 5 The IMo's Strategy is due to be updated in

1 International Maritime Organization, Reduction of GHG Emissions From Ships, Fourth IMO GHG Study 2020, Final Report, Imo Doc. MEPC 75/7/15 (29 July 2020), Annex 1, 1: International shipping accounted for $1,076 \mathrm{Mt} \mathrm{CO}_{2}$ eq. in 2018. I wish to thank Professor Seline Trevisanut and Dr Natalie Dobson for their comments on an earlier draft of this article. I am also grateful to the journal's referees for their valuable feedback. Any errors or omissions are mine alone.

2 Convention on the Intergovernmental Maritime Consultative Organization, 6 March 1948, 289 UnTs 3, as amended. A consolidated version is contained in IMo, Basic Documents, Volume I (IMO, 2010 ed.), 8-32 (hereinafter Imo Convention), Articles 1, 2, 38.

3 Imo, Report of the Marine Environmental Protection Committee on its Forty-Second Session, IMO Doc. ME PC 42/22 (16 November 1998) (hereinafter ME PC 42/22), 32-3. In the early 199os, the IMO began considering the regulation of vessel-source emissions of ozone-depleting air pollutants: Iмо, 'Prevention of Pollution By Air From Ships', Iмо Ass. Res. A.719(17), Iмо Doc. A 17/Res. 719 (4 December 1991) (hereinafter A 17/Res. 719). As discussed in Section 2, below, its deliberations on the reduction of other greenhouse gases and of shipping's impact on the climate system was initiated later that decade.

$4 \mathrm{IMO}$, Amendments to the Annex to the Protocol of 1997 to Amend the International Convention for the Prevention of Pollution From Ships, 1973, As Modified by the Protocol of 1978 Relating Thereto, IMO Doc. MEPC 203(62) (15 July 2011) (hereinafter MEPC 203(62)); IMO, Promotion of Technical Cooperation and Transfer of Technology Relating to the Improvement of Energy Efficiency in Ships, IMO Doc. MEPC 229(65) (17 May 2013) (hereinafter MEPC 229(65)); IMO, Amendments to the Annex to the Protocol of 1997 to Amend the International Convention for the Prevention of Pollution From Ships, 1973, As Modified by the Protocol of 1978 Relating Thereto, IMO Doc. MEPC 278(70) (28 October 2016) (hereinafter MEPC 278(70)).

5 IMO, 'Adoption of the Initial Imo Strategy on the Reduction of Greenhouse Gases From Ships and Existing Imo Activity Related to Reducing GHG Emissions in the Shipping Sector', IMO Doc. MEPC 304(72) (13 April 2018) (hereinafter IMO 2018 Strategy or Strategy). See Tae-Hwan Joung et al., 'The Imo Strategy for Reducing Greenhouse Gas Emissions, and its Follow-up Actions Towards 2050', (4)(1) Journal of International Maritime Safety, Environmental Affairs, and Shipping 1 (2020); Yubing Shi and Warwick Gullett, 'International Regulation 
2023. ${ }^{6}$ The shipping industry has characterized the Strategy as a 'Paris Agreement for shipping' and expressed hope that the IMo's action would deter more stringent regulation, in particular by the European Union. ${ }^{7}$

This article evaluates whether the IMO's 2018 Strategy imposed a legal obligation on the IMO to mitigate climate change from international shipping, and the scope and nature of any such obligation. Accepting that the IMO has international legal personality, can bear obligations, and incur responsibility for breaching them under international law, the article's methodology is grounded in treaty interpretation and international law's traditional sourcebased approach. ${ }^{8}$ It first discusses the IMO's mandate to reduce emissions from shipping, the treaties that together form a 'regime complex' giving rise to that mandate, and the IMO's character as a quasi-legislative organization that exercises prescriptive jurisdiction related to the effect of shipping on the marine environment (Section 2). It then briefly analyses whether that regime complex imposes a legal obligation on the IMO to reduce greenhouse gas emissions, and concludes that while the IMO bears procedural obligations to reduce marine pollution from shipping - including greenhouse gas emissions - the maritime and climate treaties do not require it to do so to a particular level (Section 3$) \cdot{ }^{9}$ In Section 4, the 2018 Strategy is scrutinized. After first summarizing the Strategy's text, I discuss the 'hitherto underexplored' legal character of unilateral declarations made by international organizations. ${ }^{10}$ Despite the relative lack of

of Low-Carbon Shipping for Climate Change Mitigation: Development, Challenges, and Prospects', 49(2) Ocean Development and International Law 134 (2018); Beatriz Foster, Anita Foerster, and Jolene Lin, 'Net Zero for the International Shipping Sector? An Analysis of the Implementation and Regulatory Challenges of the IMO Strategy on Reduction of GHG Emissions', 33(1) Journal of Environmental Law 85 (2021).

6 Iм0, 'Strategic Plan for the Organization for the Six Year Period 2018-2023', Imo Assem. Res. A.1110(30), Iмо Doc. A 30/Res.1110 (8 December 2017) (hereinafter A3o/Res. 1110).

7 'Iмо Agrees to Emissions Target', Maritime Executive (13 April 2018), <www.maritimeexecutive.com/article/imo-agrees-to-co2-emissions-target>; see Natalie Dobson, 'Competing Climate Change Responses: Reflections on EU Unilateral Regulation of International Transport Emissions in Light of Multilateral Developments', 67 Netherlands International Law Review 183 (2020) (discussing the European Union's unilateral regulation of greenhouse gas emissions from shipping).

8 See Jean d'Aspremont, Formalism and the Sources of International Law: A Theory of the Ascertainment of Legal Rules (Oxford University Press, 2011).

9 In this article, I do not consider whether customary international law obliges the IMo to reduce emissions from shipping or whether the IMo's member states have an obligation to mitigate climate change caused by international shipping.

10 Eva Kassoti and Mihail Vatsov, 'A Missed Opportunity? Unilateral Declarations by the European Union and the European Court of Justice's Venezuelan Fisheries Judgment,' 35 International Journal of Marine and Coastal Law 55 (2020), 57. 
attention to declarations of organizations, scholarship and practice indicate that they can create erga omnes legal obligations if made clearly and publicly by an organization with sufficient legal capacity and institutional competence and where there is a textual expression of an intent to assume obligations. ${ }^{11}$

That analysis is applied to the 2018 Strategy. The IMo has a legal capacity to conclude treaties on matters related to its functions and purposes, and therefore also has a capacity to unilaterally bind itself. The Strategy's text and circumstances show that the IMO intended to bind itself, and thus assumed a legal obligation to fulfill the Paris Agreement's purpose of limiting global warming. ${ }^{12}$ Because the Strategy is not addressed to any particular state but to the world at large, the IMO's obligation under it is owed erga omnes. ${ }^{13}$ It thus functions differently from an organizational 'rule' that would impose an obligation on the IMO towards its member states; ${ }^{14}$

11 Manuel Virally, 'Unilateral Acts of International Organizations', in International Law: Achievements and Prospects, edited by Mohammed Bedjaoui (Martinus Nijhoff, 1991), 256-7; see Jan Klabbers, An Introduction to International Institutional Law (Cambridge University Press, 2009), 283 (an international organization is responsible under international law 'if it does not live up to the promises it has made'); Alexander Orakhelashvili, 'The World Bank Inspection Panel in Context: Institutional Aspects of the Accountability of International Organizations', 2 International Organizations Law Review 57 (2005), 71; Ciprian N. Radavoi, 'Indirect Responsibility in Development Lending: Do Multilateral Banks have an Obligation to Monitor Project Loans?', 53 Texas International Law Journal 1 (2018); Opinion of Judge Advocate General Sharpston, Parliament and Commission v. Council, ECJ Joined Cases C-103/12 and C-165/12 (15 May 2014) (hereinafter AG Sharpston Opinion), paras 64-79.

As discussed in Section 3.4, there is disagreement about whether and how the Paris Agreement's global warming limitation goals function as legal obligations. (See, generally, Alexander Zahar 'Collective Obligation and Individual Ambition in the Paris Agreement', 9(1) Transnational Environmental Law 165 (2020).)

13 International Law Commission, 'Guiding Principles Applicable to Unilateral Declarations of States Capable of Creating Legal Obligations, With Commentaries Thereto', Yearbook of the International Law Commission, 2006, Vol. II, Part Two, Un Doc. A/61/10 (hereinafter ILC Guiding Principles), Commentary to Principle 6. I use this procedural conception of erga omnes obligations rather than the one based on the importance of the rights involved, which the ILC adopted in connection with its articles on state responsibility. (Compare ibid. and Nuclear Tests (Austr. v. Fr.), Judgment 1974 ICJ REP. 253 (20 December), 269 (hereinafter Nuclear Tests), para. 5o, with International Law Commission, 'Draft Articles on Responsibility of States for Internationally Wrongful Acts, With Commentaries', Yearbook of the International Law Commission, 2001, Vol. II, Part Two, UN Doc. A/56/10 (hereinafter Articles on State Responsibility), Commentary to Art. 1, para. 4 (citing Case Concerning the Barcelona Traction, Light and Power Company (Bel. v. Sp.), Judgment 1970 ICJ REP. 19703 (5 February), 32, para. 33).

14 Cf. International Law Commission, 'Draft Articles on the Responsibility of International Organizations', Yearbook of the International Law Commission, 2011, Vol. II, Part Two, UN Doc. A/66/10 (hereinafter DARIO), 46, 63 (Art. 10(2), providing that organizations can incur responsibility for breaching an obligation arising for it towards its members under its rules), 
and the Strategy's quality as a unilateral declaration means that it cannot be arbitrarily withdrawn. ${ }^{15}$

Treating the 2018 Strategy as a unilateral declaration creates a 'regime bridge' between the IMO and the climate treaties that would give parameters and certainty to Paris Agreement parties as they revise their NDC s (Section 5). It would thus further the Agreement's objectives. ${ }^{16}$ It would also be consistent with Mayer's argument that NDC s are unilateral declarations. ${ }^{17}$ Significant attention has been given to the fragmentation of international law, and international climate law in particular. ${ }^{18}$ Evaluating international organizations' climate policies as unilateral declarations, as is done here, could clarify and unify climate law and have broader positivist and constitutional consequences for international law. ${ }^{19}$

The Imo states that it 'is regarded as the sole competent international organization with a global mandate to regulate all non-commercial aspects of international shipping, including reduction or limitation of GHG emissions'.20 That mandate might appear uncontroversial given the climate measures

with ILC Guiding Principles, supra n. 13, Principle 6 (states may address binding unilateral declarations to the international community as a whole).

15 ILC Guiding Principles, supra n. 13, Principle 10 (criteria used to assess whether withdrawal of a declaration is arbitrary).

16 See Beatriz Martinez Romera, 'The Paris Agreement and the Regulation of International Bunker Fuels', 25(2) RECIEL 215 (2016), 222 (finding that the Paris Agreement left bunker fuels 'disconnected' from its goals).

17 See Benoit Mayer, 'International Law Obligations Arising in Relation to Nationally Determined Contributions', 7(2) Transnational Environmental Law 251 (2018).

18 See, generally, Harro van Asselt et al., 'Global Climate Change and the Fragmentation of International Law', 30(4) Law and Policy 423 (2008).

19 See Orakhelashvili, supra n. 11; Radavoi, supra n. 11 (examining whether an international lending organization's environmental policies are unilateral declarations); Jaye Ellis, 'Shades of Grey: Soft Law and the Validity of Public International Law', 25(2) Leiden Journal International Law 313 (2012), 317 (discussing the rule-creation process as a factor in the designation of international norms as law).

20 IMO, Position Paper to UNFCCC Ad-Hoc Working Group (IMO Doc. AWG-LCA 8) (17-18 December 2009), 6. Although the IMO theoretically has competence to regulate commercial aspects of shipping, the long-standing practice of its members has limited its mandate to technical rather than economic aspects of the industry, which are regulated pursuant to international trade law. (See Yubing Shi, Climate Change and International Shipping: The Regulatory Framework for the Reduction of Greenhouse Gas Emissions (Brill Nijhoff, 2017) 179-80 (discussing the IMO's mandate to regulate greenhouse gas emissions using technical means). 
that the IMO has enacted since 2011. ${ }^{21}$ Yet states and scholars disagree about whether the IMO's mandate arises from its constituent instrument- the IMO Convention - and the maritime legal regime, consisting of the 1982 UN Law of the Sea Convention (LOSC) and the 1973 International Convention on the Prevention of Pollution from Ships as modified by that treaty's 1978 Protocol (MARPOL),22 or whether it derives from the climate treaties, in particular Article 2(2) of the Kyoto Protocol..$^{23}$ The gravamen of this dispute is the sharp distinction between the 'non-discrimination' principle in the maritime regime and the CBDR principle in the climate regime, ${ }^{24}$ as well as the argument that if a particular legal regime gives the IMO its mandate, that regime's principles

21 See Section 2.2's discussion of the Imo's climate measures.

22 United Nations Law of the Sea Convention (adopted 1o December 1982, entered into force 11 November 1994) 1833 UNTS 3 (hereinafter LOSC); International Convention for the Prevention of Pollution from Ships (adopted 11 February 1973, as modified by the Protocol of 17 February 1978, entered into force 2 October 1983) 1340 UnTs 61. The registered version of the 1978 MARPol Protocol incorporates the 1973 Convention as an annex; the Convention begins at 1340 UNTS 184. I refer to the 1973 Convention as 'MARPOL', and to the 1978 Protocol as 'MARPOL 78'. As discussed below, the LOSC is as a framework convention that delegates the setting of specific standards to the IMO, which in turn has regulatory functions under MARPOL.

23 See Saiful Karim, Prevention of Pollution of the Marine Environment from Vessels (Springer, 2015), 119-20 (discussing conflict between the CBDR principle and the non-discrimination principle in the Imo's regulation of greenhouse gas emissions from shipping); Sophia Kopela, 'Climate Change, Regime Interaction, and the Principle of Common but Differentiated Responsibility: The Experience of the International Maritime Organization', 42(1) Yearbook International Environmental Law 70 (2014), 76-7; cf. Beatriz Martinez Romera, Regime Interaction and Climate Change: The Case of International Aviation and Maritime Transport (Routledge, 2018) (the IMO's mandate to regulate greenhouse gas emissions comes from IMO Assembly Resolution A63.23(2003)), 149, with Shi, supra n. 20, 179-82 (the IMo Convention and the LOSC give the IMO 'general competence' to regulate greenhouse gas emissions from shipping, and the Kyoto Protocol gave the IMo its specific mandate to do so). Scholars speak of the international law governing the regulation of emissions from shipping in terms of legal 'regimes', including the climate regime, the regime applicable to the IMO, the Law of the Sea regime as set forth in UNCLOS, and international trade law: Martinez Romera, supra n. 23 at 37-8, 100-101 (discussing 'regime interaction' where processes and actors in the climate regime and the IMO influence the regulation of emissions from shipping); Daniel Bodansky, 'Regulating Greenhouse Gas Emissions from Ships: The Role of the International Maritime Organization', in Ocean Law Debates: The 5o-Year Legacy and Emerging Issues for the Years Ahead, Harry Scheiber et. al. (eds) (Brill Nijhoff, 2016), 3 (regime 'complex' applies to regulation of emissions from shipping). This article uses the same terminology.

24 The non-discrimination principle in the Imo Convention provides that global shipping requires universal regulations equally applicable to all ships. (IMO Convention, supra n. 2, Art. 1(b).) The CBDR principle holds that all states should protect the climate system 'on the basis of equity and in accordance with their common but differentiated responsibilities and respective capabilities', and that developed countries should therefore 'take the lead in combating climate change and the adverse effects thereof' (UNFCCC, Art. 3(1)). 
should determine what measures the IMo may adopt. ${ }^{25}$ Some scholars have suggested a 'compromise' position, which is that the IMO's mandate comes from both regimes, and that the gulf between the applicable principles is not as wide as might appear. ${ }^{26}$

According to the International Court of Justice, 'the very nature of the organization created, the objectives which have been assigned to it by its founders, the imperatives associated with the effective performance of its functions, as well as its own practice' are elements that deserve attention when interpreting an organization's mandate. ${ }^{27}$ This section provides an overview of the IMO's history and institutional structure concerning vessel-source pollution, and the resolutions and instruments that together form the legal basis for the IMO's regulation of greenhouse gas emissions. It thereby sets the legal context of the 2018 Strategy and its function of bridging the maritime and climate legal regimes.

\subsection{IMO Regulation of Vessel-Source Pollution}

The IMO, founded in 1948, was originally called the Inter-Governmental Maritime Consultative Organization (IMCO). ${ }^{28}$ The IMCO had a broad purpose of serving as a forum for cooperation among its member states for almost everything related to international shipping. ${ }^{29}$ As reflected in its name, the IMCO's original conception was as a consultative rather than a regulatory organization, and was required to abstain from 'matters which appear to the Organization capable of settlement through the normal processes of international shipping business. ${ }^{30}$ It did not have an express environmental purpose, although its jurisdiction over technical matters extended to pollution

25 Yubing Shi, 'Gigantic Shipbuilders under the Imo Mandate of G HG Emissions: With Special References to China, Japan and Korea', 7(2) Journal East Asia and International Law 493 (2014), 499-501 (discussing the context and importance of the debate on the IMO's mandate to regulate emissions from shipping); Kopela, supra n. 23, $76-7$ (same).

26 Shi, supra n. 25, 8; Christian Pisani, 'Fair at Sea: The Design of a Future Legal Instrument on Marine Bunker Fuels Emissions Within the Climate Change Regime', 33(1) Ocean Development and International Law 57 (2002), 200.

27 Legality of the Use by a State of Nuclear Weapons in Armed Conflict, ICJ REP. 1996 66, Advisory Opinion (hereinafter Nuclear Weapons), 75; see also Niels Blokker, 'Constituent Instruments', in The Oxford Handbook of International Organizations, Jacob Catz Cogan, et. al. (eds) (Oxford University Press, 2016), 955-7.

28 Craig Allen, 'Revisiting the Thames Formula: The Evolving Role of the International Maritime Organization and Its Member States in Implementing the 1982 Law of the Sea Convention', 10 San Diego International Law Journal 265 (2009).

29 Michael McGonigle and Mark Zacher, Pollution, Politics, and International Law: Tankers at Sea (University of California Press, 1979), 40-1; IMO Convention, supra n. 2, Art. 1.

30 McGonigle and Zacher, supra n. 29, 40. 
control by virtue of its sponsorship of conferences on the 1954 Oil Pollution Convention and its consideration of oil-pollution prevention as part of maritime safety. ${ }^{31}$ In its specialized-agency agreement with the IMCO under Article 57 of the UN Charter, the UN General Assembly endorsed the IMco's broad purpose of regulating international shipping, recognizing it as 'responsible for taking such action as may be appropriate under its basic instrument for the accomplishment of the purposes therein'. ${ }^{32}$

In the 1970s, concurrent with the drafting and adoption of MARPOL, the IMO Assembly enacted a series of amendments to the IMco Convention. Those amendments gave the organization its current name and created the Marine Environment Protection Committee (MEPC). They also provided that the IMO 'is to encourage and facilitate the general adoption of the highest practicable standards in matters concerning ... the prevention and control of marine pollution from ships. ${ }^{33}$ In order to achieve this aim, the IMO considers and makes recommendations on matters concerning the IMO remitted to it by its members; provides for the drafting and recommendation of conventions and other instruments; and provides machinery for consultation among its members, in particular on matters assigned to it 'under international instruments relating to maritime matters and the effect of shipping on the marine environment. ${ }^{34}$ Thus the Imo Convention does not limit the type of marine pollution that can be controlled by IMO regulations, nor the method by which regulation can be achieved. ${ }^{35}$

The MEPC is composed of all IMO members, and has specific functions under the IMo Convention that are expressly tied to other international conventions. ${ }^{36}$ Pursuant to IMO Convention Article 38 , the MEPC may consider any matter within the scope of the organization related to the prevention and control of marine pollution from shipping. Under clause (a) of that article, it performs 'such functions as are or may be conferred upon the Organization by or under international conventions for the prevention and control of marine pollution from ships'; ${ }^{37}$ and under clause (e), it may consider and take

$31 \quad$ Ibid., 41.

32 G.A. Res. 204 (III), Un Doc A/REs/204(III) (18 Nov. 1948), 61 (adopting the Economic and Social Council Resolution 165(VII), 27 August 1948 (collectively, hereinafter, IMo Specialized Agency Agreement), Art. II. The ICJ refers to specialized agency agreements to interpret international organizations' purposes and functions: Nuclear Weapons, supra n. 27, para. 26. IMo Convention, supra n. 2, Art. 1.

34 Ibid., Art. 2.

35 Aoife O'Leary and Jennifer Brown, The Legal Basis for IMo Climate Measures (Environmental Defense Fund and Sabin Center for Climate Change Law, Columbia Law School, 2018), 2.

36 Imo Convention, supra n. 2, Art. 11 (designating the MEPC as an IMO organ); and Art. 37 (all members of the IMO are members of the MEPC).

37 Ibid., Art. 38(a). 
'appropriate action with respect to any other matters falling within the scope of the Organization which would contribute to the prevention and control of marine pollution from ships. ${ }^{38}$

MARPOL establishes discharge and emission standards for ships. ${ }^{39}$ It requires its state parties to 'give effect' to it and to 'those Annexes thereto by which they are bound, in order to prevent the pollution of the marine environment by the discharge of harmful substances.40 MARPOL's annexes cover categories of 'harmful substances', including noxious liquid substances, garbage, and air pollution. ${ }^{41}$ Annexes I and II are mandatory, in that any party that wishes to join MARPOL must adopt them; Annexes III, IV, V, and VI are 'optional' and must be separately ratified. ${ }^{42}$ MARPOL designates the IMO as the 'appropriate body' for the drafting and adoption of MARPOL annexes and amendments to annexes. ${ }^{43}$ The MEPC performs that function, and when adopting or amending MARPOL annexes, it has consistently cited Imo Convention Article 38(a), which refers to the conferral of functions on it by other conventions. ${ }^{44}$

MARPOL annexes can be amended in two ways. An amendment can be adopted by MARPOL parties acting within the MEPC with a two-thirds majority vote. It will be deemed accepted if two-thirds of parties to the Annex representing at least 50 per cent of the gross tonnage of the world's merchant fleet affirmatively accept it. ${ }^{45}$ Alternatively, under a 'tacit-amendment' procedure, a two-thirds majority within the MEPC can amend a MARPOL annex by deeming an amendment to have been accepted at the end of a period ... not less than ten months, unless within that period an objection' is lodged by one-third of MARPOL's parties representing at least 50 per cent of gross tonnage. ${ }^{46}$ There is no legal distinction between these types of amendment,

38 Ibid., Art. 38(e).

39 As discussed by Bodansky, the IMo regulates greenhouse gas emissions and other pollutants with technical vessel-based standards rather than through national discharge totals: Bodansky, supra n. 23, 8 .

4 MARPOL, supra n. 22, Art. 1(1).

41 Saiful Karim, 'Implementation of the marpol Convention in Developing Countries', 79 Nordic Journal International Law 303 (2010), 312-13. MARPOL imposes other obligations on its signatories related to its effective implementation, such as requirements that port and coastal states prosecute violations; see MARPOL, supra n. 22, Art. 4.

42 See marpol 78 , supra n. 22, Art. 2.

43 MARPOL, supra n. 22, Art. 16(2). Amendments to Marpol or its Annexes can also be made by a cop: ibid., Art. 16(3). See Martinez Romera, supra n. 23, 101, fn. 477 (the Imo's power to regulate greenhouse gas emissions under the Iм0 Convention comes from Article 38 ).

44 See, e.g., MEPC 203(62), supra n. 4; MEPC 278(70), supra n. 4.

45 MARPOL, supra n. 22, Art. 16(2)(d) and (f)(i).

46 Ibid., Art. 16(2)(f)(ii) and (iii)); see Karim, supra n. 23, 36-7 (discussing the tacit-amendment procedure); O'Leary and Brown, supra n. 35, 18 (same). 
although in practice the tacit-amendment procedure is used for 'technical provisions whose details are less controversial. ${ }^{47}$ Scholars have concluded that MARPOL's tacit-amendment procedure-and similar procedures in other IMO treaties dealing with shipping safety and navigation-imbue the IMO with a 'quasi-legislative' rather than a merely consultative institutional character. ${ }^{48}$

Under the LOSC, flag states retain primary prescriptive jurisdiction over ship design, construction, and operation, but they must adopt rules that have 'at least the same effect' as generally recognized international standards for the control of marine pollution from vessels, and must take internationally agreed standards 'into account' when regulating 'pollution of the marine environment from or through the atmosphere' from vessels, aircraft, and airspace under their sovereignty. ${ }^{49}$ The IMO is a recognized source of these standards under the LOSC, ${ }^{50}$ and as the Imo Secretary-General explained, "while [the LOSC] defines the features and extent of the concepts of flag, coastal, and port State jurisdiction, IMO instruments specify how State jurisdiction should

47 Rüdiger Wolfrum, 'Iм0 Interface with the Law of the Sea Convention', in Current Maritime Issues and the International Maritime Organization, Myron H. Nordquist and John Norton Moore (eds) (Martinus Nijhoff, 1999), 227.

48 Frederic L. Kirgis, Jr., 'Shipping', in United Nations Legal Order, Volume II, Oscar Schacter and Christopher C. Joyner (eds) (The American Society of International Law/Cambridge University Press, 1995), 718-23 (evaluating the IMO's 'meaningful quasi-legislative authority' under its tacit-amendment procedure and the Losc); Wolfrum, supra n. 47, 232 ('only due to [the tacit acceptance] procedure, one may argue, does the Iмо exercise prescriptive jurisdiction over vessel-source pollution'); Allen, supra n. 28.

49 LOSC, supra n. 22, Articles 94, 211, 212, 218, 222. Under the LOSC, coastal and port states can also enact and implement vessel-source pollution rules beyond international standards in certain circumstances depending on the type of pollution and on the maritime zone: ibid., Articles 211(3) and (6), 212; see, generally, Erik Molenaar, Coastal State Jurisdiction over Vessel Source Pollution (Kluwer Law International, 1998).

$5^{\circ}$ See, ibid. (Molenaar), ${ }^{136-37}$ (the Iмо is the 'competent international organization' on vessel-source pollution, although it shares competence with regard to monitoring standards with the International Labor Organization and radioactive substances with the International Atomic Energy Agency). Whether the IMo's greenhouse gas regulations operate as a floor or as standards that states merely need to 'take into account' depends in part on whether the regulations concern 'pollution of the marine environment from vessels' within the meaning of LOSC Art. 211, or 'atmospheric pollution' under Art. 212. (Bodansky, supra n. 23, 9-10.) For its part, the MEPC has referred to greenhouse gas emissions as both 'air pollution' and 'marine pollution from ships': 2018 Strategy, supra n. 5, 1 (in enacting the Strategy, the MEPC referenced its functions concerning 'international conventions for the prevention and control of marine pollution from ships'); Annex 2, 1 (describing the regulation of greenhouse gas emissions as part of reduction of 'air pollution from ships'). The answer to that question is beyond the scope of this article. 
be exercised to ensure compliance with safety and antipollution shipping regulations. 51

The allocation of enforcement jurisdiction in the LOsC broadens the reach of IMO standards beyond the parties that adopt them: even if a state does not ratify a MARPOL annex or amendment, ships flying its flag have a strong incentive to comply with the standards in force because port states have universal enforcement jurisdiction over violations of 'applicable international rules and standards established through' the IMO; and coastal states may enforce those rules and standards for violations that occur within their exclusive economic zones and territorial seas. ${ }^{52}$ Moreover, pursuant to the principle of no-more-favorable treatment, MARPOL obliges its parties to apply the Convention and its annexes to non-parties. ${ }^{53}$ Thus, under MARPOL and the LOSC, a vessel engaged in international shipping may very well find itself subject to an IMO pollution-control standard at various points in its journey, regardless of its nationality. ${ }^{54}$ Scholars have concluded that the breadth, depth, and wide reach of the IMO's environmental standards, MARPOL's tacit-amendment procedure, and

$5^{1}$ Iмо, Executive Summary, Relations with the United Nations and the Specialized Agencies, Note by the Secretary General, IMO Doc. C/ES.19/19(b)/1, with attached Study on the Implications of the Entry into Force of the United Nations Law of the Sea Convention, IMO Doc. LEG/MISC/2, 6 October 1997; reproduced in Netherlands Institute for the Law of the Sea, 13 International Organizations and the Law of the Sea: Documentary Yearbook 767 (1997), 804. See Molenaar, supra n. 49, 113-14 (the LOSC and MARPOL impose a maximum level of prescriptive jurisdiction on a coastal state; port states retain 'residual' jurisdiction under general international law to go beyond regulatory conventions).

52 LOSC, supra n. 22, Articles 218, 220; see, generally, Jesper Jarl Fanø, Enforcing International Maritime Legislation on Air Pollution Through UNCLOS (Bloomsbury, 2019), 135-7, 188-98 ('discharges' under LOSC Art. 218(1) include air pollution emitted from ships).

53 MARPOL, supra n. 22, Articles 5(4), 16(4)(a); see Imo, IMO Assembly Resolution 'Procedures for Port State Control, 2017', imo Doc. A 30/Res.1119 (6 December 2017), Annex, 4-5 (discussing MARPOL Annexes' provisions for port-state control over ships of non-parties); Molenaar, supra n. 49, 114 (discussing the impact for flag states of opting out of MARPOL amendments).

54 Wolfrum, supra n. 47, 231 (under the LOSC 'the power to invoke rules and standards [by port and coastal states] does not depend on whether the flag State of that particular ship is a party to the relevant Convention'); 232 (the Losc delegates prescriptive jurisdiction to the IMO; its 'rules, regulations and standards again become part of the legal regime established by and on the basis of' the LOSC). Kirgis argues that the LOSC establishes a legal obligation to implement IMO norms regarding environmental protection, and that the good-faith principle extends that obligation to LOSC non-parties: Kirgis, supra n. 48, 739-40; see also Augustín Blanco-Balzán, 'Iм0 Interface with the Law of the Sea Convention', in Current Maritime Issues and the International Maritime Organization, Myron H. Nordquist and John Norton Moore (eds) (Martinus Nijhoff, 1999), 282 ('even on the high seas, a ship party to UNCLOS violates the Convention if it does not comply with discharge requirements under MARPOL'). 
the references in the LOSC to the IMO, give the IMO a law-making character markedly different from the IM Co's limited consultative mandate. ${ }^{55}$

\subsection{IMO Regulation of Greenhouse Gas Emissions}

Starting in the 1990s, the IMO began considering action on greenhouse gas emissions from shipping, and called on states to take voluntary measures as it weighed the possibility of mandatory regulations. ${ }^{56}$ When the MARPOL COP adopted an annex for air pollution in 1997, it called on the MEPC to develop a greenhouse-gas-reduction strategy for shipping, and referred to Article 2(2) of the Kyoto Protocol, which obliges Annex I parties to 'work through' the Imo to reduce or limit emissions from international shipping. ${ }^{57}$ A 1998 MEPC report affirms the IMO's 'clear mandate to deal with emissions from shipping', 'in response to the Kyoto Conference'. 58

Within the MEPC, there was lengthy debate about the legal basis for the IMO's mitigation of shipping emissions, particularly in the lead-up to the UNFCCC's 2009 Copenhagen COP. The dispute was between developed and developing countries, with the former arguing that the IMO has an independent mandate to regulate pollution from shipping, including greenhouse gas emissions, while developing countries maintained that the IMo's mandate is

55 See the sources cited at notes 49 and 54; Alfred Popp, "The Treaty-Making Work of the Legal Committee of the International Maritime Organization', in The Regulation of International Shipping: International and Comparative Perspectives: Essays in Honor of Edgar Gold, Aldo Chircop et. al. (eds) (Martinus Nijhoff, 2012), 210 (the IMO initially functioned as a consultative body without binding standard-setting powers, but 'over the years the Organization has evolved').

56 See Kopela, supra n. 23, 75-7; Martinez Romera, supra n. 23, 101-2; A 17/Res. 719, supra n. 3; Iмо, Report to the Marine Environmental Protection Committee On Its Thirty-Ninth Session, Imo Doc. MEPC 39/13 (25 April 1997), para. 6.30; MEPC 42/22, supra n. 3, para. 9.18; IMO, Report to the Marine Environmental Protection Committee On Its forty-Fifth Session, Imo Doc. MEPC 45/20 (15 October 2000) (hereinafter MEPC 45/20), para 8.17-8.19; IMO, Report to the Marine Environmental Protection Committee On Its forty-Eighty Session, I Mo Doc. ME PC 48/21 (24 October 2002), para. 4.12; Iмо, Report to the Marine Environmental Protection Committee On Its Forty-Ninth Session, Addendum 1, Imo Doc. MEPC 49/22/Add.1 (13 August 2003), Annex 7, 1; Iмо, 'Iмо Policies and Practices Related to the Reduction of Greenhouse Gas Emissions From Ships', Imo Ass. Res. A.963(20) (4 March 2004) (hereinafter A.963(20)), preamble, paras 1, 2; Iмо, Report to the Marine Environmental Protection Committee On Its Fifty-Fourth Session, IMO Doc. MEPC 54/21 (27 March 2006) (hereinafter MEPC 54/21), para. 4.32.

57 Kopela, supra n. 23, 75-6; see MEPC 45/20, para. 8.14.

$5^{8}$ MEPC 42/22, supra n. 3, para. 9.18. 
based on the climate regime. ${ }^{59}$ This debate was linked to a disagreement about the principles that should apply to the IMO's regulation of emissions and the differential climate obligations among IMO members. ${ }^{60}$ Despite the disagreement, the Imo Convention's dispute-resolution procedures on the interpretation of its provisions were never triggered. ${ }^{61}$

In 2008, the IM O's Secretary-General noted that, under Article 59 of the IMO Convention, the IMO was 'the specialized agency of the United Nations in the field of shipping and the effect of shipping on the marine environment', and 'thus, had a global mandate and global competence on matters related to the protection of the environment from emissions caused by shipping and was not subordinated to any other UN body in that respect.' ${ }^{62}$ The IMO's official position at the Copenhagen COP was that it wanted to ensure that the international community entrusted it with responsibility to 'develop and enact global regulations for GHG emissions from shipping' in light of its 'specific mandate of effectively protecting and preserving the global environment, both marine and atmospheric'.63 The Iм0 was motivated by its desire to maintain its 'leading position to avoid unilateral action' by states or regional organizations. ${ }^{64}$

The IMO's first mandatory greenhouse-gas-reduction measures were the 2011 Energy Efficiency Design Index and Ship Energy Efficiency Management Plan-technical and operational measures aimed at reducing emissions

59 See imo, Report to the Marine Environmental Protection Committee On Its Fifty-Eighth Session, IMO Doc. MEPC 58/23 (16 October 2008) (hereinafter MEPC 58/23), Annex 9, 1, 11 (China argued that the UNFCCC and Kyoto Protocol 'should be the legal basis for IMO to address the issue of GHG emission reduction from international shipping', while the United States asserted that 'Iм0's mandate to regulate GHG emissions from shipping predates, and does not derive from, the Kyoto Protocol').

6o See, e.g., Imo, Report to the Marine Environmental Protection Committee On Its FortyEighth Session, Imo Doc. MEPC 48/21, 2003 (24 October 2002), para. 4.18 (China and other developing states arguing that СBDR should apply, and obligation to mitigate shipping's climate impact was borne only by UNFCCC Annex I countries).

61 Imo Convention, supra n. 2, Articles 74 and 75 (disputes among Imo member states about the interpretation of the convention may be submitted to the Assembly for resolution, and then to the ICJ for an advisory opinion).

62 MEPC 58/23, supra n. 59, para. 4.30. The IMO Convention was re-numbered in 2010, and Article 56 is now Article 64 .

63 IMo, Submission by the International Maritime Commission, United Nations Climate Change Conference, Eighth Session of the Ad-Hoc Working Group On Long Term Cooperative Action (AWG-LCA 8) (7-18 December 2009), 2.

64 Iмо, Report to the Marine Environmental Protection Committee On Its Fifty-Fifth Session, iмо Doc. MEPC 55/23 (15 October 2006), para. 4.25. Natalie Dobson shows how the IMo's climate policy was developed in response to the threat of unilateral action from the European Union: Dobson, supra n. 7 . 
from shipping by increasing energy efficiency. ${ }^{65}$ In 2013, the MEPC adopted technical-assistance measures related to the 2011 regulations. ${ }^{66}$ In 2016 , it created a mandatory data-collection system for fuel-oil consumption. ${ }^{67}$ In June 2021, the MEPC amended the Energy Efficiency Design Index to require, among other things, that large ships calculate their annual operational carbon intensity. ${ }^{6}$

The instruments effecting these actions reference the IMo Convention and MARPOL for their legal basis, with limited and sporadic reference to the climate regime. This legal framing is consistent with the views of the IMO's legal office that MARPOL's Article 2 is the source of the IMO's mandate to regulate emissions from shipping, as well as with the fact that those regulations could be characterized as both climate measures and part of an effort to 'modernize the shipping industry by making it more energy and cost efficient'. 69 Accordingly, the 2011 energy-efficiency measures 'recognized' that the measures did not 'prejudge' the ongoing UNFCCC negotiations. ${ }^{70}$ The resolution adopting the 2013 technical-assistance measures was 'cognizant' of both the no-more favorabletreatment principle under the IMO Convention and the CBDR principle under the UNFCCC and Kyoto Protocol; as for the mandatory data-collection system for fuel-oil consumption, it did not mention the climate treaties. ${ }^{71}$

In 2017, the IMO Assembly noted the importance of the Paris Agreement and the challenge of climate change, and resolved that the Imo would respond to climate change as one of its 'strategic directions. ${ }^{72}$ In adopting

65 MEPC 203(62), supra n. 4; Karim, supra n. 20, 109-10; Fano, supra n. 52, 264-5.

66 MEPC 229(65), supra n. 4; see Karim, supra n. 20, 120-3 (discussing the adoption and implementation of the measure in light of the CBDR and no-more-favorable treatment principles).

67 MEPC 278(70), supra n. 4; Dobson, supra n. 6, 193-5 (comparing the IMo's global data collection scheme for greenhouse gas emissions to European Union's monitoring, reporting, and verification scheme).

68 IMO, 'Meeting Summary Marine Environment Protection Committee (MEPC 76) 10-17 June 2021 (remote session)', <www.imo.org/en/MediaCentre/MeetingSummaries/Pages/ MEPC 76 meetingsummary.aspx>; IMO, Note by the Secretariat, 'Consideration and Adoption of Amendments to Mandatory Instruments, Draft Amendments to MARPOL Annex VI', IMO Doc. MEPC 75/3 (26 July 2019).

69 Kopela, supra n. 23, 77 (discussing the Imo's position on its mandate and finding that the IMO has independent competence to regulate greenhouse gas emissions from shipping).

70 The 2011 measure is frequently referred to by the IMO and others as its flagship response to climate change (e.g., Martinez Romera, supra n. 23, 103). The measure did not specifically state that it was designed to reduce greenhouse gas emissions, but instead recognized that the measures would result in a reduction of 'any substances that originate from fuel oil or its combustion processes' (MEPC 203(62), supra n. 4).

71 MEPC 229(65), supra n. 4; MEPC 278(70), supra n. 4.

72 A 30/Res.1110, supra n. 6, 6. 
its 2018 greenhouse gas Strategy, the MEPC invoked IMO Convention Article $38(\mathrm{e})$, which, as noted earlier, provides that the MEPC is to 'consider and take appropriate action' on any matters 'related' to the prevention and control of vessel-source marine pollution. The MEPC also acknowledged the 'continuous' work that the Imo had done on climate change since $1997 .{ }^{73}$ Thus, the Imo has long interpreted its mandate to control greenhouse gas emissions from shipping as arising from its constituent instrument, which, together with the IMo's specialized-agency agreement with the United Nations, grants it primacy as the international organization responsible for regulating shipping's environmental impacts. As scholars have argued, the objectives of MARPOL and the climate regime with regard to international shipping are the same: the reduction and limitation of vessel-source pollution, including greenhouse gas emissions. ${ }^{74}$ In Section 4, I will discuss how the 2018 Strategy incorporates the Paris Agreement's goals and thus links the two regimes in a legally meaningful way.

IMO Obligations to Mitigate Climate Change under the IMo Convention, MARPOL, and Climate Treaties

The fact that an international organization has a right to act in a certain way does not mean that it has an obligation to do so. ${ }^{75}$ International organizations are bound by 'obligations incumbent upon them under general rules of international law, under their constitutions or under international agreements to which they are parties.76 They can also be bound to treaty obligations as non-signatory third parties pursuant to Article 35 of the Vienna Convention on the Law of Treaties Between States and International Organizations or Between International Organizations (VCLT-IO). ${ }^{77}$ This section first examines whether the Iм0 has procedural and substantive climate obligations under

73 IMO 2018 G HG Strategy, supra n. 5, Annex 1, 1.

74 Kopela, supra n. 23, 76-7; Pisani, supra n. 26, 6o; Sebastian Oberthür, 'Institutional Interaction to Address Greenhouse Gas Emissions from International Transport: ICAO, IMO and the Kyoto Protocol', 3(3) Climate Policy 191 (2003), 200.

75 Vienna Convention on the Law of Treaties, 1155 UnTS 331, 23 May 1969 (hereinafter VCLT (1969)), Articles 34-37 (discussing the difference between rights and obligations).

76 Interpretation of the Agreement of 25 March 1951 between the wHO and Egypt, Advisory Opinion, ICJ REP. 73 (December 1980), para. 37.

77 Vienna Convention on the Law of Treaties between States and International Organizations or Between International Organizations, 25 ILM 543, 21 March 1986 (hereinafter VCLT-IO), Art. 35; Kristina Daugirdas, 'How and Why International Law Binds International Organizations', 57(2) Harvard International Law Journal 325 (2016), 326, 335 (noting that 
its constitution and MARPOL, and then evaluates whether it has obligations under the climate treaties. ${ }^{78}$

\subsection{IMO Obligations under Its Constitution and MARPOL}

Article 2 of the IM O Convention states that the IMO 'shall' consider and make recommendations related to the IMO's purpose of preventing and controlling marine pollution; provide for the drafting of conventions and recommend them to governments 'as may be necessary'; provide machinery for consultation; and perform functions that other international agreements impose on the Iмо, in particular related to shipping's environmental effects. Article 38 imposes procedural obligations on the MEPC:

[The MEPC] shall consider any matter within the scope of the Organization concerned with the prevention and control of marine pollution from ships and in particular shall ... [p] erform such functions as are or may be conferred upon the Organization by or under international conventions for the prevention and control of marine pollution from ships [and] [c] onsider and take appropriate action with respect to any other matters falling within the scope of the Organization which would contribute to the prevention and control of marine pollution from ships.

The word 'shall' in the Imo Convention, as in treaties generally, indicates the imposition of a mandatory duty on the IMO and its organs. ${ }^{79}$ Thus, pursuant to Articles 2 and 28 of the Imo Convention, the IMO is obliged to act as a forum for its member states to prevent and control pollution from shipping, and take

the VCLT-IO has not yet entered into force, and scholars dispute aspects of its applicability, including whether treaties can bind organizations without their consent).

78 See Pulp Mills on the River Uruguay (Argentina v. Uruguay), Judgment, 2011 ICJ REP. 14 (20 April), 47 (hereinafter Pulp Mills), paras. 67-158 (discussing the distinction between substantive and procedural obligations); Stefan Talmon, 'Jus Cogens after Germany v. Italy: Substantive and Procedural Rules Distinguished', 25(4) Leiden Journal of International Law 979 (2012), 982 (obligations bear on whether conduct is lawful or not, while 'procedural rules are rules governing the judicial and non-judicial interpretation, implementation, and enforcement of substantive rules'). As discussed in the following section, there has been significant research on whether the climate change treaties themselves impose procedural or substantive obligations: see Zahar, supra n. 12, 170-1 (collecting scholarship).

79 Constitution of the Inter-governmental Maritime Safety Committee, Advisory Opinion, 196o ICJ REP. 15 O (8 June), 159, 164 (interpreting Article 28 of the Convention as imposing mandatory obligations on the IMCo Assembly). 
'appropriate action' with respect to other matters that would contribute to pollution prevention and control. 80

The IMo's obligation to perform these functions should be interpreted consistently with its purposes. ${ }^{81}$ IMO Convention Article 1(a) defines one of the organization's purposes as encouraging and facilitating 'the general adoption of the highest practicable standards in matters concerning ... prevention and control of marine pollution from ships. ${ }^{2}$ Accordingly, the IMo, when making recommendations to its members, providing machinery for consultation, or considering and taking appropriate action to control vessel-source pollution, must aim to encourage its member states to adopt the highest practicable standards.

MARPOL also imposes procedural obligations on the IMO, stating that the IMO 'shall' notify MARPOL's member states of certain types of information and convene conferences in defined circumstances. ${ }^{83}$ It also provides that the IMO is to act as the forum for MARPOL's member states to consider any amendment to MARPOL's annexes. ${ }^{84}$ MARPOL is not, of course, the IMO's constituent instrument, nor is the IMO a party to MARPOL, yet it appears that the IMO is nevertheless bound by these provisions as a 'third organization' within the meaning of Article 35 of the VCLT-IO, which states that the parties to a treaty may impose an obligation on a third organization, which it may accept if 'the obligation arises in an area of activity of the organization' and if consent is 'given expressly and in writing'. ${ }^{85}$ Here, the procedural obligations that MARPOL's parties imposed on the IMO arise in its area of activity as a regulatory

8o Although Article 38 by its terms imposes obligations only on the MEPC, the MEPC's conduct in the performance of its functions 'shall be considered an act of [the IMO] under international law': DARIO, supra n. 14, Art. 6(1). Article 38 can therefore be read to impose obligations on both the IMO and the MEPC.

81 Pulp Mills, supra n. 78, para. 173 (a treaty's purpose informs the interpretation of obligations).

82 Imo Convention, supra n. 2, Art. 1(a). Article 1(a) itself does not impose an obligation on IMO: the text of the Convention captions Article 1 as 'purposes', and Article 2 as 'obligations'; and the ICJ has distinguished between treaty purposes and obligations where the text supports a distinction: Pulp Mills, supra n. 78, para. 173 (the treaty's purpose 'does not by itself lay down specific rights and obligations').

83 See MARPOL, supra n. 22, Articles 2(7) (defining the IMO as an 'organization' under MARPOL), 11(2), 14(4); 15 (the IMO 'shall notify' parties of various communications, declarations, and acts of member states); 16 (MARPOL and its annexes may be amended, and new annexes to MARPOL may be adopted, after consideration by the IMO).

84 Ibid., Art. 16(2).

85 Caroline Laly-Chevalier, '1986 Vienna Convention, Observance, Application and Interpretation of Treaties: Treaties and Third States', in The Vienna Conventions on the Law of Treaties, Oliver Corten and Pierre Klein (eds) (Oxford University Press, 2011), 1; VCLTIO, Art. 35, supra n. 77. As noted above, scholars disagree about aspects of the VCLT-IO, 
forum for international shipping. The IMO, when adopting a new MARPOL annex, as well as when amending an annex, invokes Imo Convention Article 38(a) - which allows the IMO to perform functions assigned to it by other international instruments. ${ }^{86}$ Through these resolutions, the IMo has accepted MARPOL obligations expressly and in written form.

Yet MARPOL does not oblige the IMO to reduce pollution from shipping in any particular way. The only obligation in MARPOL related to the quantum of the pollution that must be reduced is its requirement that its parties 'give effect' to it and to 'those Annexes thereto by which they are bound, in order to prevent the pollution of the marine environment by the discharge of harmful substances'. ${ }^{87}$ Thus MARPOL's member states are only obliged to implement the convention and its annexes, which restrict the means of discharge but generally allow for margins of vessel-source pollution. ${ }^{88}$ The treaty isolated from its annexes does not impose a substantive obligation to mitigate climate change, whether on its member states or on the Iмо.

\subsection{IMO Obligations under the Climate Treaties}

The climate treaties on their face do not appear to bind the Iмо. The Iмо is not a party to the UNFCCC and therefore cannot join the Kyoto Protocol or the Paris Agreement. ${ }^{89}$ Of the three treaties, only the Kyoto Protocol, in Article 2(2), refers to the IMO, where it requires Annex I parties to 'work through' the IMO to achieve emission reductions from bunker fuels. ${ }^{90}$ As I noted in Section 2 , the MEPC referred to that provision in its early deliberations on greenhouse gas emissions from shipping. Yet, Article 2(2) does not bind the IMO as a 'third organization' under VCLT-IO Article 35, because its phrasing does not show

including about its provisions on the acceptance of obligations by non-party international organizations: see Daugirdas, supra n. 77, 335; Christian Tomuschat, 'International Organizations as Third Parties Under the Law of International Treaties', in The Law of Treaties Beyond the Vienna Convention, Enzo Cannizzaro (ed.) (Oxford, 2011), 206, 211-12.

86 See, e.g., MEPC 203(62), supra n. 4 (amending MARPOL Annex VI to add EEDI requirements and referring to IMо Convention Article $38(\mathrm{a})$ ).

87 MARPOL, supra n. 22, Art. 1(1); see resolutions discussed in Section 1, above. MARPOL's Annexes I and II are mandatory, in that any party that wishes to join MARPOL must adopt them; Annexes III, IV, V, and VI are 'optional' and therefore must be separately ratified. (See MARPOL 78, supra n. 22, Art. 2; Karim, supra n. 41, 312-13.) MARPOL imposes other obligations on its signatories related to its effective implementation, such as requirements that port and coastal states prosecute violations. (See MARPOL, supra n. 22, Art. 4.)

88 See Karim, supra n. 41, 315-16 (MARPOL only completely bans the discharge of plastic pollution into the sea; dangerous chemicals and oils may still be discharged in specified locations if certain methods are followed).

89 UnfCCC, Art. 20; Kyoto Protocol, Art. 24(1); Paris Agreement, Art. 20.

90 Kyoto Protocol, Art. 2(2). 
that the Protocol's signatories intended such an obligation to arise. ${ }^{91}$ Moreover, as already noted, the MEPC did not formally invoke the Kyoto Protocol in its climate resolutions, and therefore did not 'expressly accept' any obligation from that treaty in writing. ${ }^{92}$

Even in the absence of a textual indication that the IMO is bound by the climate treaties' obligations, the Imo might be indirectly bound through its member states based on the concept of functional succession. This doctrine holds that international organizations, as 'peers' of states within the international legal order, can succeed to their members' powers as well as obligations linked to those powers. The concept's underlying 'rationale relies on the obligations existing prior to conferral of power' ${ }^{93}$

In the present case, in 1982, the IMo's member states-as well as the parties to MARPOL and the LOSC - gave the IMO authority to act as the exclusive forum for the setting of global standards for the control of vessel-source pollution. ${ }^{94}$ Because the UNFCCC was concluded some ten years after the prevention and control of vessel-source pollution was expressly added to the IMo's purposes and functions, it appears that the Imo could not have succeeded to its member states' climate obligations. One might even argue that the IMO did not have competence to regulate atmospheric pollution until 1997, when MARPol's Air Pollution Protocol (Annex VI) and Resolution 8 were adopted by MARPOL's COP. Nevertheless, the IMO Convention and LOSC give the IMO its charge of regulating 'vessel-source pollution' without restricting the type of pollution within the IM O's prescriptive jurisdiction. ${ }^{95}$ In addition, the IM O was first created some fifty years before the UNFCCC was adopted. Therefore, this situation differs sharply from the cases of International Fruit and South-West Africa, where an international organization succeeded to rights and obligations held at the time when the organization was created. ${ }^{96}$

91 See VCLT-IO, supra n. 77, Art. 35 (obligation arises for third organization 'from the provision of a treaty if the parties to the treaty intend the provision to be the means of establishing the obligation'); VCLT (1969), supra n. 75, Art. 31(1) ('A treaty shall be interpreted in good faith in accordance with the ordinary meaning to be given to the terms of the treaty').

92 VClT-IO, supra n. 77, Art. 35 .

93 Dobson, supra n. 7, 17; see Daugirdas, supra n. 77, 350-7, 369; International Status of South-West Africa, Advisory Opinion 1950 ICJ REP. 128, 132-8; Joined Cases 21 to 24/72, International Fruit Company NV v. Produktschap voor Groenten en Fruit, 1972 ECR 1219 (hereinafter International Fruit), para. 18. The European Court of Justice decided International Fruit - a court that was itself part of the European Community: see Treaty Establishing the European Community, Rome, 25 March 1957, Official Journal C325, Art. 4. See Section 2, above.

95 Imo Convention, supra n. 2, Articles 2 and 38.

96 See cases cited at note 93 . 
Ultimately, the binding of international organizations to their members' substantive treaty obligations is only required when necessary to avoid or resolve treaty conflicts. ${ }^{97}$ There does not appear to be any conflict between the IMo's obligation to act as a forum for the reduction of emissions from shipping, on the one hand, and, on the other, its members' obligations under Article 4 of the UNFCCC to reduce or limit emissions from all forms of transportation, as well as their obligation under Articles 2 and 3 of the Paris Agreement to hold global warming below $2^{\circ} \mathrm{C} .{ }^{98}$ Moreover, as Daugirdas argues, the resolution of conflicts is best settled by the states which bear substantive treaty obligations that may conflict with an organization's constituent instrument. ${ }^{99}$ As discussed in the next section, any treaty conflict between the principles in the maritime and climate regimes was addressed by the IMO members in the 2018 Strategy.

\section{The IMo's 2018 Strategy as a Unilateral Declaration}

International organizations routinely act unilaterally in the form of decisions, recommendations, and judicial and administrative acts authorized by their constituent instruments. ${ }^{100}$ The formal elements and factual circumstances of a particular unilateral action by the IM O- the Strategy - are examined here to determine whether its characteristics allow for it to be classified as a binding unilateral declaration - in addition to being an IMO 'rule'.101

\subsection{The 2018 Strategy}

The MEPC adopted the Strategy in April 2018, marking the first time the IMO set a cap for shipping's emissions. The Strategy explains how it will achieve reductions to comply with the cap. In the preamble to the resolution adopting the Strategy, the MEPC 'recalled' Imo Convention Article 38(e), which, to reiterate, obliges the MEPC to 'consider and take appropriate action' regarding any matter falling within the scope of the IMO that would contribute to the prevention and control of marine pollution from shipping. The MEPC stated that it would keep the Strategy under review with a view to adopting a revised strategy five years later. ${ }^{102}$ The Strategy's introduction casts it as a continuation of

97 Daugirdas, supra n. 77, 350.

$98 \quad$ UNFCCC, Articles 2 and 4; Paris Agreement, Articles 2 and 3.

99 Daugirdas, supra n. 77, 350-1 (citing vCLt (1969), supra n. 75, Articles 30(2)-(3) and 59).

100 Virally, supra n. 11, 242-5. See ILC Guiding Principles, supra n. 13, para. 174 (discussing conceptual definitions of unilateral acts). See DARIO, supra n. 14, Art. 2 (organizations are bound by their 'rules' and 'general principles of international law'). 
the IMO's work on greenhouse gas emissions that builds on the 2003 Assembly resolution and the MEPC's 2011, 2013, and 2016 measures. Under the heading 'Context', the Strategy identifies other legal instruments, including the Losc, the UNFCCC, and the Paris Agreement. ${ }^{103}$ It also lists the IMo's 'leading role' in the development, adoption, and assistance with the implementation of environmental regulations for shipping, the IMO Assembly's 2017 decision to respond to climate change as a 'strategic direction', and the UN 2030 Agenda for Sustainable Development. ${ }^{104}$

The Strategy lists its objectives as 'enhancing IMO's contribution to global efforts by addressing GHG emissions from international shipping. The global efforts include 'the Paris Agreement and its goals', as well as Goal 13 of the UN 2030 Agenda for Sustainable Development, which calls for taking urgent action to combat climate change and its impacts. The Strategy's vision is that the 'IMO remains committed to reducing GHG emissions from international shipping and, as a matter of urgency, aims to phase them out as soon as possible in this century'105

The Strategy sets out three 'Levels of Ambition.' First, the 'carbon intensity of the ship [is] to decline through implementation of further phases of the energy efficiency design index (EEDI) for new ships', with the percentage improvement to be determined for each ship type. ${ }^{106}$ Second, the 'carbon intensity of international shipping [is] to decline to reduce $\mathrm{CO}_{2}$ emissions per transport work, as an average across international shipping, by at least $40 \%$ by 2030, pursuing efforts towards $70 \%$ by 2050 , compared to 2008 '. Lastly, emissions from international shipping are to peak

as soon as possible and [there is to be a reduction of] the total annual GHG emissions by at least $50 \%$ by 2050 compared to 2008 whilst pursuing efforts towards phasing them out as called for in the Vision as a point on a pathway of $\mathrm{CO}_{2}$ emissions reduction consistent with the Paris Agreement temperature goals. ${ }^{107}$

The Strategy sets forth relevant legal principles from the maritime and climate regimes, and refers to the no-more-favorable-treatment principle alongside the CBDR principle. It also identifies 'candidate' short-, mid-, and long-term further measures, which include financing adaptation activities, technology

\begin{tabular}{ll}
\hline 103 & Ibid., 4-5. \\
104 & Ibid., 5. \\
105 & Ibid., 5. \\
106 & Ibid., 6. \\
107 & Ibid., 6.
\end{tabular}


transfer and cooperation, and capacity building. ${ }^{108}$ It concludes with a quinquennial timeline for periodic revisions. ${ }^{109}$

\subsection{Unilateral Declarations of International Organizations}

States' ability to bind themselves with unilateral declarations is firmly established in international law, as is the test for when a state's conduct or statements give rise to a legal obligation and when declarations can be revoked. ${ }^{110}$ The test requires that the person or entity making the declaration have authority to do so. ${ }^{111}$ The declaration must be a clear and public expression, in specific terms, of an intent to be bound. ${ }^{112}$ If those conditions are met, the declaration becomes binding based on the principle of good faith, and states are 'entitled to take them into consideration and rely on them, and require that such obligations be respected.'113 A declaration may be addressed to a specific state or to the international community as a whole. ${ }^{114}$ Obligations imposed by declarations are to be interpreted restrictively, and in 'interpreting the content of such obligations, weight shall be given first and foremost to the text of the declaration, together with the context and the circumstances in which it was formulated'. ${ }^{115}$ If a unilateral declaration that creates a legal obligation is made, the declaration cannot be arbitrarily revoked. ${ }^{116}$

108 Ibid., 7-10. It appears that these measures will mix voluntary programs and regulations enacted as amendments to MARPOL Annex vi: see Joung et al., supra n. 5 .

Imo Strategy, supra n. 5 , 10. The MEPC resolution adopting the Strategy included the Strategy as Annex I; it also included an Annex II that discusses in narrative form the Imo's work on greenhouse gas emissions. Case Concerning the Frontier Dispute (Burkina Faso v. Rep. Mali), Judgment, 1986 ICJ REP. 554 (22 December) (hereinafter Frontier Dispute) 573, para. 39; Legal Status of Eastern Greenland, Judgment 1933 PCIJ Series A/B, No. 53 (5 April) (hereinafter Legal Status of Eastern Greenland), 71; ILC Guiding Principles, supra n. 13. The ILC's Guiding Principles and their accompanying commentary 'are explanatory notes reviewing the jurisprudence of the International Court of Justice and pertinent State practice analysed by several members of the Working Group and the Special Rapporteur and summarized in the eighth report of the Special Rapporteur (A/CN.4/557)': ibid. 369, fn. 921.

111

112 Ibid., Principle 4. Ibid., Principles 4, 7 . Ibid., Principle 1. Eva Kassoti persuasively argues that 'the distinction between sources of law and sources of obligation is largely irrelevant on the international level', and therefore unilateral acts can be regarded as sources of law in the same manner as international agreements: The Juridical Nature of Unilateral Acts of States in International Law (Brill Nijhoff, 2015), 178.

ILC Guiding Principles, supra n. 13, Principle 6.

Ibid., Principle 7.

Ibid., Principle 10. 
In contrast to the well-developed test for unilateral declarations of states, there have been no international judicial decisions on international organizations' capacity to bind themselves with their statements- or on the test to be applied. Nor has the International Law Commission addressed the question. At the UN General Assembly proceedings on the Unilateral Acts of States, member states indicated that the unilateral acts of international organizations 'could be genuine unilateral legal acts', but 'such acts were very specific and therefore required special rules'.17 The Special Rapporteur on the Unilateral Acts of States commented that 'unilateral acts performed by an organ of an international organization or by an international organization as such may have legal force', but that they are 'performed as a result of the competence which States themselves have conferred on the body and of which they may become the object'.118 Accordingly, the competence of an organization to perform such an act is 'regulated by the law peculiar to each international organization.'119

There is scholarly support, following that logic, for the idea that organizations, as subjects of international law, can bind themselves with unilateral acts. ${ }^{120}$ Moreover, the idea was explored in an opinion by Advocate General (AG) Sharpston in the Venezuelan Fisheries case before the European Court of Justice. ${ }^{121}$ The case concerned Decision 2012/19 of the EU Council, which was captioned as a 'Unilateral Declaration' making certain commitments regarding Venezuela's access to fisheries within French Guiana's exclusive economic zone. ${ }^{122}$ The Council adopted the Decision following the EU Commission's recommendation; the Commission's view was that the declaration would be legally equivalent to an international agreement. ${ }^{123}$ The Council asked the EU Parliament to give its opinion on the measure, but it declined, and the Council then adopted Decision 2012/19. ${ }^{124}$ The Commission and Parliament sued in the European Court of Justice to annul the Decision, arguing it had a wrong

\footnotetext{
117 Víctor Rodríguez Cedeño, Second Report on Unilateral Acts of States, UN Doc. A/CN.4/50o (14 April 1999) (hereinafter Cedeño Second Report), para. 16 (citing statements by Italy, Bahrain, Switzerland, Germany, and the United States).

118 Víctor Rodríguez Cedeño, First Report on Unilateral Acts of States, UN Doc. A/CN.4/486 (5 March 1998) (hereinafter Cedeño First Report), para. 35 .

119 Ibid., para. 38 .

120 See sources cited at notes 10 and 11.

121 AG Sharpston Opinion, supra n. 11. See also Kassoti and Vatsov, supra n. 10.

122 AG Sharpston Opinion, supra n. 11, para. 2.

123 Ibid., para. 34 .

124 Ibid., para. 48.
} 
legal basis, did not respect the prerogatives of Parliament, and distorted the Commission's proposal. ${ }^{25}$

AG Sharpston analysed the legal nature of the Council's decision. She examined whether it constituted a unilateral declaration with independent legal effects, or was part of an international agreement that had effects only once it was accepted by the party to which it was addressed-Venezuela. ${ }^{126}$ The Council maintained that the declaration was a unilateral instrument but also an element of an international agreement. ${ }^{127}$ The AG noted that none of the parties at a hearing before Parliament 'could offer examples of other unilaterally binding instruments adopted by the EU or by other intergovernmental organizations'. ${ }^{128}$ Nonetheless, the AG opined that there was no rationale for 'why international law would preclude an international organization with international legal personality from having the capacity to make a unilateral declaration with the intention to be bound as long as the constitutive treaties establishing that organization authorize it to do so', and reasoned that such a view was consistent with the capacity of organizations to enter into treaties and other international agreements. ${ }^{129}$ The AG found that the EU had both the capacity and the competence to unilaterally bind itself under international law. ${ }^{130}$ The AG then applied the test for when a unilateral act of a state creates binding obligations. ${ }^{131}$ In examining whether the declaration was made under a proper authority, she noted that although the EU's constituent instrument did not expressly authorize unilateral declarations, it did allow the EU to accept obligations in favour of third states and international organizations. The founders of the EU clearly wanted the EU to have international legal personality and all the capacities that international law attaches to that status - including the capacity to be unilaterally bound. It followed that the declaration was made with the requisite authority. ${ }^{132}$ Examining the text of the declaration and its context, the AG concluded that the EU Council's Decision

\footnotetext{
125 Ibid., para. 2.

126 Ibid., para. 72.

127 Ibid., para. 69 .

128 Ibid., para. 70.

129 Ibid., para. 86, 87.

$130 \quad$ Ibid., para. 86, 94-7.

131 Ibid., para. 9o; see also cases cited at supra n. 110, and ILC Guiding Principles, supra n. 13.

132 AG Sharpston Opinion, supra n. 11, para. 96, 100-1 (citing Consolidated Versions of the Treaty on European Union and the Treaty on the Functioning of the European Union, Art. 218, 2010 O.J. (C83), 2012 O.J. (C326) (hereinafter TFEU)).
} 
was a binding unilateral declaration, albeit one that was incorrectly adopted under European law. ${ }^{133}$

The European Court of Justice decided the case on a different basis and did not discuss AG Sharpston's analysis of whether the EU's decision was a unilateral declaration. ${ }^{134}$ As Kassoti and Vatsov state, the court's judgment 'represents a missed opportunity (through engaging with the AG's Opinion) to shed light' on unilateral acts of international organizations. ${ }^{135}$ Yet, in the absence of a judicial decision, the AG's opinion provides a valuable analytical roadmap for how to evaluate the legal force of international organizations' declarations.

As the Special Rapporteur pointed out, unilateral acts have other legal effects besides the creation of obligations, including the acceptance of, and reservations to, treaties. ${ }^{136}$ The VCLT-IO allows organizations to accept treaties and make reservations to them, and some organizations have done just that. ${ }^{137}$ The ILC has opined that treaty reservations by states and international organizations should be interpreted in the same manner. ${ }^{138}$ And it makes sense to draw parallels between treaty-making and unilateral acts, where 'unilateral acts can and have been used as an alternative to treaties in cases where the normal path of concluding an international agreement is unavailable on grounds of political expediency' ${ }^{\prime} 139$ In addition, international organizations can and do engage in unilateral political acts on the world stage, with significant policy consequences. ${ }^{140}$ Organizations' ability to act unilaterally on the international plane thus provides a strong foundation on which to consider whether their statements qualify as unilateral declarations intended to create legal obligations.

Moreover, 'it has long been recognized that the customary international law of state responsibility applies mutatis mutandis' to international

\footnotetext{
133 Ibid., paras 102, 207.

134 ECJ Joined Cases C-103/12 and C-165/12, Parliament and Commission v. Council, Judgment of the Court, 26 Nov. 2014: ECLI:EU:C:2014:2400, paras 52-83.

135 Kassoti and Vatsov, supra n. 10, 57.

136 Cedeño First Report, supra n. 118, 331; see also Alfred Rubin, 'The International Legal Effects of Unilateral Declarations', 71(1) American Journal of International Law 1 (1977), 5.

137 See vCLT-IO, supra n. 77, Art. 35. The European Union is a party to a number of treaties, including the LOSC and the UNFCCC: Kassoti and Vatsov, supra n. 10; Dobson, supra n. 7.

138 Orakhelashvili, supra n. 11, 481 (discussing the ILC's guidelines on interpretations of reservations).

139 Kassoti and Vatsov, supra n. 10, 57. See also Kassoti, supra n. 113, 104.

140 Dobson, supra n. 7 (analysing the EU's unilateral climate actions with respect to aviation and maritime emissions). There is debate on whether unilateral acts should be regarded as political and legal, or as merely political, with some scholars casting 'doubt on the legal nature of such acts': Kassoti, supra n. 113, 27 (providing a literature review). I agree with Kassoti that, consistent with international jurisprudence, unilateral acts have legal effects and can be sources of international law: ibid., 178 .
} 
organizations. ${ }^{141}$ Thus the ILC's definition of 'obligation' for the purposes of the international responsibility of states and of international organizations is the same. For organizations, as with states, obligations 'may be established by a customary rule of international law, by a treaty or by a general principle applicable within the international legal order'. ${ }^{142}$ As Reinisch notes, 'general principles of law are often considered to be directly applicable law for international organizations. ${ }^{\prime 13}$ Given that the binding nature of unilateral acts of states is based on the general principle of good faith, ${ }^{144}$ an international organization's obligation to comply with that same principle encompasses an obligation to comply with its unilateral declarations.

\subsection{Was the 2018 Strategy a Unilateral Declaration?}

This section first evaluates whether the IMO has the requisite legal personality to unilaterally bind itself under international law, as well as whether the MEPC has the competence to bind the IMO to a greenhouse-gas-reduction strategy under the Imo Convention. It then analyses the 2018 Strategy to see if it qualifies as a unilateral declaration, and the obligations that it imposes if it does.

\subsubsection{IMO Capacity to Unilaterally Bind Itself}

AG Sharpston's analysis of whether the EU could bind itself was rooted in its capacity to conclude an international agreement under its constituent instrument. However, the capacity of international organizations to conclude treaties is limited and differentiated. They 'possess the capacity to conclude treaties which is necessary for the exercise of their functions and the fulfillment of the purposes', as governed by their rules, defined as the 'constituent instruments, decisions and resolutions adopted in accordance with them and established practice of the organization.' ${ }^{145}$

\footnotetext{
141 Radavoi, supra n. 11, 4.

142 Compare DARIO, supra n. 14, Art. 10, with Articles on State Responsibility, supra n. 13, Art 12 .

143 August Reinisch, 'Sources of International Organization Law: Why Custom and General Principles Are Crucial', in Oxford Handbook on Sources of International Law, Jean d'Aspremont and Samantha Besson, (eds) (Oxford University Press, 2018), 1022 (discussing case law and practice of international organizations).

144 Nuclear Tests, supra n. 14, para. 46 ('just as the very rule of pacta sunt servanda in the law of treaties is based on good faith, so also is the binding character of an international obligation assumed by unilateral declaration').

145 VCLT-IO, supra n. 77, preamble and Articles 6 and 2(1)(j). See, generally, Klabbers, supra n. 11, 41 (discussing organizations' treaty-making capacity). There have been many judicial decisions as well as voluminous scholarship on the limited competence and powers of international organizations; see, e.g., Nuclear Weapons, supra n. 27, para. 25.
} 
The IMO's constituent instrument does not explicitly grant it a general capacity to enter into international arrangements with other organizations or states. ${ }^{146}$ It does provide that the IMO 'shall' enter into an arrangement with the United Nations to become a UN specialized agency pursuant to Article 57 of the UN Charter, and that 'the legal capacity, privileges and immunities to be accorded to, or in connexion with, the Organization, shall be derived from and governed by the General Convention on the Privileges and Immunities of the Specialized Agencies.' ${ }^{147}$ The General Convention grants specialized agencies juridical personality and the capacity to contract, acquire, and dispose of property and institute legal proceedings. ${ }^{148}$ The IMO, in addition to its specialized-agency agreement with the United Nations, has concluded a headquarters agreement with the government of the United Kingdom. ${ }^{149}$ Under both of these agreements, the IMO was granted legal rights and undertook obligations, indicating that it has international legal personality consistent with its purposes and functions, and juridical personality within domestic legal orders. ${ }^{150}$

As discussed in Section 2, the IMO has broad purposes and functions to regulate emissions from shipping, and it therefore has legal capacity to bind itself consistently with those purposes and functions, whether unilaterally or through an international agreement. The European Union possibly has a greater legal capacity than the Iмо to unilaterally bind itself: its constituent instrument expressly grants it the ability to conclude treaties, and it has done so on many occasions; moreover, it is regarded by the ILC as a 'special case' among international organizations because of the high degree of integration between it and its members. ${ }^{151}$ Yet, there is no reason to treat the European

146 Compare tFEU, supra n. 132, Art. 218, with Imo Convention, supra n. 2, Art. 69.

147 Imo Convention, supra n. 2, Articles 64, 69 (the Imo's legal capacity is derived from, and governed by, the General Convention on the Privileges and Immunities of Specialized Agencies, 16 Aug. 1949, 33 UNTS 261 (hereinafter General Convention)). General Convention, supra n. 147, Art. II, section 3.

149 See Imo, 'Agreement With the Host State Regarding Extension of Privileges and Immunities to Permanent Representatives and Divisional Directors', Imo Assem. Res. A.9o8(22), IMO Doc. A22 Res/9o8 (25 January 2002) (amending and approving headquarters agreement); Imo Specialized Agency Agreement, supra n. 32.

150 Ibid.; and Niels Blokker, 'Juridical Personality (Article II Section 3 Specialized Agencies Convention)', in The Conventions on the Privileges and Immunities of the United Nations and its Specialized Agencies: A Commentary, August Reinisch (ed.) (Oxford University Press, 2016), 52-3 (the General Convention concerns the ability of specialized agencies to contract within domestic legal systems; it 'is not about the legal status of the Specialized Agencies in the international legal order'). 
Union's declarations as having more legal force than the IMo's based on differences between the two organizations' legal personality. International organizations have international legal personality consistent with their purposes and functions. ${ }^{152}$ While the IMO might not have the capacity to make a unilateral declaration with a legal effect beyond its limited personality, it does have the necessary capacity with regard to the 2018 Strategy at issue here.

\subsubsection{MEPC Competence to Bind the IMO to a GHG-Reduction Strategy for Shipping}

The ILC's Guiding Principles provide that 'persons representing the State in specified areas may be authorized to bind it, through their declarations, in areas falling within their competence', and the ICJ has noted that persons representing a state in specific fields, in addition to heads of state or government, are increasingly authorized to bind their states with their statements. ${ }^{153}$ In addition, the unilateral acts of international organizations or their organs 'are performed as a result of the competence which States themselves have conferred on the body and of which they may become the object'. ${ }^{154}$ Here, the MEPC - which under the IMO Convention is authorized to carry out the IMO's functions related to the prevention and control of marine pollution from shipping - was competent to bind the IMo with a unilateral declaration related to the regulation of greenhouse gas emissions from shipping. ${ }^{155}$

\subsubsection{The 2018 Strategy as a Unilateral Declaration}

The 2018 Strategy has been characterized as a mere 'political document'.156 But as Kassoti states, an objective and manifest intention to be bound is the

Reparation for Injuries Suffered in the Service of the United Nations, Advisory Opinion, 1949 ICJ Rep 174 (11 April); see also Henry Schermers and Niels Blokker, International Institutional Law (5th ed., Brill Nijhoff, 2011), 99o.

153 ILC Guiding Principles, supra n. 13, Principle 4; Case Concerning Armed Activities on the Territory of the Congo, New Application 2002 (Dem. Rep. of the Congo v. Rwanda), Judgement, 2006 ICJ REP 6 (3 February) (hereinafter Armed Activities), para. 47.

154 Cedeño First Report, supra n. 118, para. 38.

155 My position is that the MEPC was competent to bind the IMO through a unilateral declaration; I do not argue in this article that the MEPC bound the IMO's member states. See, generally, Klabbers, supra n. 11, 271-2 (discussing the 'layered nature' of legal relationships between international organizations and their members and questioning secondary and indirect legal responsibility).

${ }_{15} 6$ Aldo Chircop, 'The Imo Initial Strategy for the Reduction of GHG Emissions from International Shipping: A Commentary', 34 International Journal Marine and Coastal Law 482 (2018), 509 ('The IMO GHG Strategy is a political rather than a legal document'). 
dividing line between unilateral political acts and unilateral legal acts. ${ }^{157}$ The Strategy's terms and factual circumstances show Imo had such an intent, and the Strategy therefore qualifies as a unilateral legal act.

The publicity requirements for a unilateral declaration appear to have been met, as the Strategy was debated and adopted in a public forum, and was transmitted to the international community through the UNFCCC's Talanoa Dialogue. ${ }^{158}$ Unlike the EU Decision at issue in Venezuelan Fisheries, the Strategy is not captioned as a unilateral declaration. But 'it is generally accepted that the form of a unilateral declaration does not affect its validity or legal effects', 159 and international courts have recognized statements of policy, including oral statements, as unilateral declarations. ${ }^{160}$ Thus the Strategy's name is not dispositive, and 'the sole relevant question is whether the language employed in any given declaration does reveal a clear intention'; in other words, the question is whether the text of the Strategy objectively manifests the IMO's intention to be bound by it. 161

The Strategy's language reveals the Imo's clear intent to be bound. The Strategy uses mandatory rather than precatory terms: the IMO states that it is 'committed to reducing GHG emissions from international shipping'; and the quantified targets set out in the Levels of Ambition 'direct' the Strategy,

Kassoti, supra n. 113, 143 .

ILC Guiding Principles, supra n. 13, Principle 4; 2018 I mo Strategy, supra n. 5, 1. ILC Guiding Principles, supra n. 13, Commentary on Principle 5, 74. Some scholars question whether law identification should analyse intent rather than written indicators of legal status such as whether statements are labelled as legally binding: e.g. d'Aspremont, supra n. 8 at 178-81, 192. I adopt the generally accepted approach as expressed by the ILC and ICJ caselaw.

In Nuclear Tests, the ICJ has recognized a series of statements made by the French government that were not captioned as 'declarations' as giving rise to a binding obligation. (Nuclear Tests, supra n. 14, 265-78.) In Legal Status of Eastern Greenland, the Permanent Court of International Justice found that an oral statement by Norway's Foreign Minister that his government 'would not make any difficulties in the settlement' of a diplomatic dispute was a unilateral declaration: Legal Status of Eastern Greenland, supra n. 110, 71. State practice shows that unilateral declarations can take many different forms, including protests, proclamations, and note verbales; see Víctor Rodríguez Cedeño, Eighth Report on Unilateral Acts of States, UN Doc. A/CN.4/557 (26 May 2005) (hereinafter Cedeño Eighth Report), paras 85 and 99 (protests by the Russian Federation against Turkmenistan and Azerbaijan); 106-7 (statements by nuclear weapon states before an international body); 127 (Truman Proclamation of 1945); 140-2 (Swiss statements concerning the United Nations and its staff members).

Nuclear Tests, supra n. 14, 278 (quoting Temple of Preah Vindar, Preliminary Objections, Judgement, 1962 ICJ REP 17 (26 May), 32). 
including its measures and principles. ${ }^{162}$ Thus the Strategy sets forth in binding language the IMO's climate policies and a substantive standard to which they will be held - an emission-reduction pathway consistent with the Paris Agreement's objective.

The IMo's language more clearly shows a binding intent than France's declaration in the Nuclear Tests Cases or Norway's in Legal Status of Eastern Greenland. France said that it 'would be in a position' to change its nuclear-testing policy, and that it 'would take steps' to do so, while Norway said that it 'would not make any difficulties' regarding a diplomatic dispute. In contrast, the IMO is 'committed' to a course of action, and has made that commitment by means of a resolution adopted under Article 38(e) of its Convention, namely the provision that authorizes it to 'consider and take appropriate action' related to the control of pollution from shipping.

In addition, the IMO's intention is expressed with specificity. 'The use of broad terms and the absence of a precise timeframe for carrying out the commitment usually indicate a political act and not a binding undertaking.' ${ }^{\prime 63}$ The ICJ found that an official's statement that 'all reservations to human rights treaties will be withdrawn' was insufficiently specific to qualify as a unilateral declaration. ${ }^{164}$ Here, in contrast, the IMO committed itself to achieving a quantified absolute reduction in overall GHG emissions from shipping, on top of a reduction in the carbon intensity of shipping, by $2050 . .^{165}$

'In order to assess the intentions of the author of a unilateral act, account must be taken of all the factual circumstances in which the act occurred.166 The factual circumstances of the 2018 Strategy were that it was the culmination of a series of decisions by the IMO Assembly and the MEPC wherein the IMO repeatedly stated that it, itself, was the sole competent organization for the global regulation of greenhouse gas emissions from international shipping. ${ }^{167}$ The circumstances also include that the European Union had pressured the IMO to act through its unilateral regulation of emissions from ships visiting its ports; consequently, the IMO's adoption of a GHG-reduction policy came to be viewed by the IMO's member states as necessary for it to maintain its leading role. ${ }^{168}$ The Strategy's factual context supports viewing it as a legal undertaking, in other words, as the taking of an action which both the actor and those

\footnotetext{
$162 \quad 2018$ Strategy, supra n. 5, 5-6.

163 Kassoti, supra n. 113, 154.

164 Armed Activities, supra n. 153, para. 45.

1652018 Strategy, supra n. 5, 6.

166 Frontier Dispute, supra n. 110, 574.

167 See Section 2.

168 Dobson, supra n. 7, section 3.2.
} 
affected by it conceived of as being pursuant to a legal responsibility of the actor to address.

The ICJ has stated that 'even greater caution' should be exercised in finding a binding intent when a unilateral declaration has no specific addressee. ${ }^{169}$ The Strategy is not addressed to anyone in particular. It was transmitted to the UNFCCC as comprising the international shipping sector's 'input' on the mitigation of climate change. Nevertheless, even viewed cautiously, the Strategy's clear, specific, mandatory language and its factual circumstances indicate that the IMO intended to bind itself to the vision and levels of ambition which the Strategy sets forth, as well as to the principles and specific measures contained within it. Because the IMO made this declaration erga omnes, any resulting obligation is likewise owed to all. ${ }^{170}$

\subsection{International Obligations Imposed on the IMO by the 2018 Strategy}

Having determined that the IMO intended to bind itself with the 2018 Strategy, what substantive legal obligations did it impose upon itself? Bearing in mind that obligations created by declarations are to be interpreted restrictively, this section examines 'first and foremost ... the text of the declaration, together with the context and the circumstances in which it was formulated'.171

The terms of the 2018 Strategy indicate that the IMO has an obligation of conduct to mitigate climate change; in other words, that it is required to act diligently to meet its promise. ${ }^{172}$ The promise in the Strategy's 'Vision' is that the IMO 'remains committed' to reducing ' $G \mathrm{HG}$ emissions from international shipping and, as a matter of urgency, aims to phase them out as soon as possible in this century'. On its face, this appears to be a weak obligation - the IMO only states that it will reduce shipping emissions and 'aims' to phase them out. Yet, the Vision's relatively general terms should be interpreted consistently with the specific provisions of the rest of the document. ${ }^{173}$ One of the Strategy's

$169 \quad$ Frontier Dispute, supra n. 110, 574.

170 See ILC Guiding Principles, supra n. 13, Commentary on Guiding Principle 8 (citing Cedeño Eighth Report, supra n. 160).

171 Ibid., Principle 7.

172 See Benoit Mayer, 'Obligations of Conduct in the International Law on Climate Change: A Defence', 27 RECIEL 130 (2018), 131 (civil law obligation of conduct 'requires an endeavor towards the thing which has been promised').

173 The interpretative maxim 'noscitur a sociis' has 'received some degree of recognition in the jurisprudence and literature of international law': Arnold McNair, The Law of Treaties (Oxford University Press, 1986), 393. The law of treaties can be referenced to interpret unilateral declarations 'to the extent compatible with [their] sui generis character' (Fisheries Jurisdiction (Spain v. Canada), Judgment, 1998 ICJ REP. 432 (4 December), 453, para. 46). 
objectives is that the IMO 'contribute' to the Paris Agreement's goals, and its declared level of emission-reduction ambition amounts to an effort to phase them out 'as called for in the Vision as a point on a pathway of $\mathrm{CO}_{2}$ emissions reduction consistent with the Paris Agreement temperature goals' Thus, the terms of the Strategy, read together, incorporate the Paris Agreement's Article 2 global warming limitation goals into the IMO's mitigation obligation.

The Strategy's context and circumstances are consistent with interpreting the Strategy in this way. Leading up to the adoption of the Strategy, the MEPC members stated that the Strategy was intended 'to be able to demonstrate real progress to the UNFCCC'. They noted that the Paris Agreement did not include a 'fair share for shipping', and that, in light of the Paris Agreement, 'a failure to take action on shipping will disappoint'. ${ }^{174}$ They also stated that 'other international and regional bodies should not determine shipping's fair share to mitigate climate change. ${ }^{175}$ Although the member states disagreed about whether there should be an absolute cap for reductions from shipping, there was wide agreement that the Strategy was the shipping industry's 'contribution' to achieving the Paris Agreement's goals. ${ }^{176}$

What does it mean for the Imo to have such an obligation? The Paris Agreement's global warming limitation goals are one of its central and most intensely debated features. ${ }^{177}$ Articles 3 and 4 of the Agreement state that the global warming limitation goals of Article 2 are to be achieved through parties' NDC s and through their 'best efforts' to reach global peaking of emissions as soon as possible. ${ }^{178}$ Scholars have characterized the limitation goals as a

174 Imo, Report to the Marine Environmental Protection Committee on its Seventieth Session, IMO Doc. MEPC 70/18 (11 November 2016), 48.

175

176 Ibid.

See IMo, International Shipping's Share in International Efforts to Limit the Rise of Global Average Temperature: Submitted by Antigua and Barbuda, Belgium, Côte d'Ivoire, Denmark, France, Germany, the Marshall Islands, Monaco, Morocco, Solomon Islands, and Tonga, I мо Doc. MEPC 70/7/6 (19 August 2016), 3 (the Strategy should refer to the IPCC to ensure that shipping makes its 'fair share' to global reductions in emissions); I мо, Report to the Marine Environmental Protection Committee On Its Seventieth-First Session, IMO Doc. ME PC 71/17 (24 July 2017), 43 (China and India wanted the Strategy to be 'durable, balanced and provide confidence', drawing on the experience of the Paris Agreement); Imo, Report to the Marine Environmental Protection Committee On Its Seventy-Second Session, Annex 16, IMO Doc. MEPC 72/17/Add.1 (18 May 2018), 29 (Saudi Arabia disagreed with the level of ambition for reduction but stated that 'any ambition must be in line with the spirit of Paris Agreement'). When the Strategy was adopted, the United States had announced its intention to withdraw from the Paris Agreement, therefore the Strategy's references to the Agreement 'were without prejudice' to that country's position (ibid., 30).

Zahar, supra n. 12, 175-7 (surveying literature).

Paris Agreement, Articles 3 and 4.1. 
'collective obligation', the subject of 'collective responsibility', and as a particularly strong objective which nevertheless does not impose any binding legal obligation, whether collective or individual. ${ }^{179}$

Regardless of whether the Article 2 goals impose any sort of obligation, by unilaterally declaring that the Imo would 'contribute' to them, and by specifying levels of ambition for shipping's reduction in emissions, the IMo functionally became a party to the Paris Agreement and bound itself to its declared mitigation ambition. Parties are obliged to submit NDC s that reflect 'their highest possible ambition.'. ${ }^{180}$ In setting out the levels of ambition it would apply to shipping, the Strategy thus served as a type of sectoral contribution, from a heretofore uncovered sector. Article 4.2 of the Paris Agreement states that parties 'shall pursue domestic measures, with the aim of achieving' their NDC s' objectives. ${ }^{181}$ The Strategy likewise establishes how the IMO will realize its levels of ambition by listing 'candidate' measures, including efficiency regulations, market-based mechanisms, technology transfer, capacity building, and technical cooperation for Least Developed Countries and Small-Island Developing States. ${ }^{182}$

If the 2018 Strategy is a unilateral declaration imposing a legal obligation, the Imo cannot 'arbitrarily' revoke it. ${ }^{183}$ The Strategy provides that its levels of ambition for reductions may be revised according to various criteria, including new information about emissions from shipping, new technology, and IPCC reports. ${ }^{184}$ This provision is similar to the Paris Agreement's requirement that parties submit successive NDC s that represent a 'progression' beyond their current commitments. ${ }^{185}$ The Strategy does not specify whether future revisions will lead to greater or lesser reductions from shipping. However, in discussions on the Strategy, the Imo member states noted that the Paris Agreement called

179 See Zahar, supra n. 12, 172-4, 177 (discussing legal commentary on the Paris Agreement as imposing collective obligations and concluding that Article 4.1 imposes a strong collective aim but does not impose a collective obligation); Jaqueline Peel, 'Climate Change', in André Nollkaemper and Illias Plakokefalos (eds), The Practice of Shared Responsibility in International Law (Cambridge University Press, 2017), 1028 (the 'softness' of the Paris Agreement's Article 4(1) language 'thwarts attempts to define specific obligations applicable to any state party or a collective of parties'); see also Mayer, supra n. 17, 252, 257 (Article 2.1 imposes a collective aspiration).

$180 \quad$ Paris Agreement, Art. 4.2.

181 Mayer, supra n. 172, 130-1 (Article 4.2 imposes an 'obligation of conduct' for parties to use their best efforts to enact measures that realize their promised reductions). See 2018 Strategy, supra n. 5, 5-6, 8, 14-15.

183 ILC Guiding Principles, supra n. 13, 10.

1842018 Strategy, supra n. 5, 5.

185 Paris Agreement, Art. 4(2) and (3). 
for progressively more ambitious reduction targets, and that the IMO should likewise strengthen its reduction target every five years. ${ }^{186}$ The Strategy does not provide that its 'vision' of reducing and eliminating emissions might itself change; instead, it provides that the Strategy's objective of articulating the IMO's 'contribution to global efforts by addressing G HG emissions from international shipping', including the Paris Agreement, will remain. ${ }^{187}$ Thus the structure of the Strategy indicates that the IMO does not envisage withdrawal of its declaration, but that it might revise portions of it consistently with its overall goals-i.e. non-arbitrarily.

Because the IMO did not reserve for itself autonomy to revoke the Strategy, its termination or withdrawal would require an assessment of whether the international community relied on the IMo's declaration, and if there had been a fundamental change in circumstances. ${ }^{188}$ Given that the IMo functionally and formally contributed to the Paris Agreement's goal of limiting global warming in a way that is practically identical to a party to the Agreement, it is difficult to envision that it could revoke the Strategy and its legal obligation to mitigate climate change in a non-arbitrary manner.

\section{The 2018 Strategy as the IM o's Bridge to the Climate Regime and as a Model for International Organizations' Climate Policies}

The legal disconnect between the IMO and the climate regime is well documented. ${ }^{189}$ But, interpreting the IMO's 2018 Strategy as a unilateral declaration

186 See Iмо, GHG Emissions Reduction Target of International Shipping Based on Energy Efficiency, Submitted by Japan, Imo Doc. MEPC 70/7/3 (19 August 2016), paras 8-9 (Japanese position at MEPC ahead of adoption of 2016 Roadmap for GHG Reductions); Imo, 'Note by the Secretariat, Reduction of GHG Emissions From Ships, Report of the Second Meeting of the Intersessional Working Group on Reduction of GHG Emissions From Ships (ISWG-GHG 2)', Imo Doc. MEPC 72/7 (3 November 2017), 25-6 (member states' discussion of need for periodic review of the Strategy in order to align and provide synergy with the Paris Agreement).

1872018 Strategy, supra n. 5, 5 .

188 The ILC's Guiding Principles state that arbitrariness of withdrawal is assessed according to three criteria: the declaration's specific terms on revocation; the extent to which those to whom obligations are owed relied on the declaration; and the extent to which there has been a fundamental change in circumstances: ILC Guiding Principles, supra n. 13, Principle 10.

189 Oberthür, supra n. 74; Kopela, supra n. 23; Martinez Romera, supra n. 23. See also Ellen Hey, 'Regime Interaction and Common Interests in Regulating Areas Beyond National Jurisdictions', in Regime Interaction and Ocean Governance: Problems, Theories and 
can serve as a bridge between the maritime and climate regimes that furthers the Paris Agreement's goals, and as a model for other international organizations.

Zahar explains how the Paris Agreement's lack of 'individuation'-in other words, its vagueness about how each party should contribute to the global warming limitation goals-hinders the achievement of those goals. ${ }^{190} \mathrm{He}$ notes that the 2023 Global Stocktake called for in the Agreement could, if political will allows, serve as a forum for its parties to assess and debate how individual levels of ambition for reductions are collectively contributing to the achievement of the global warming limitation goals. Non-party stakeholders, including international organizations, will be invited to submit inputs to that stocktake. ${ }^{191}$ If the IMO-which, in preparing its 2018 Strategy, studied how shipping can contribute its 'fair share' to mitigating climate change in pursuit of the Agreement's goals - contributes to the stocktake, it would be in a good position to further the individuation narrative called for by Zahar and thus further the collective progress towards achieving the purpose of the Agreement'. ${ }^{192}$

In response to concerns that the Paris Agreement's parties will fail to live up to the promised contributions in their NDC s, Mayer argues that NDC s themselves are (or can be) unilateral declarations. He claims that viewing them as such invests at least some NDC s with 'double-bindingness': binding under the Agreement and binding as free-standing instruments of international law. ${ }^{193}$ The flexibility implied by his analysis allows non-parties to the Paris Agreement that submit an NDC, such as Taiwan, which "declared" an NDC in $2015,{ }^{194}$ to be brought within the Agreement's legal rubric, and could have implications for climate commitments made by subnational entities. ${ }^{195}$ As shown here, the law of unilateral declarations also allows for an international organization with the requisite legal capacity and competence to participate in the climate regime even if it is not a party to the UNFCCC.

Methods, Seline Trevisanut et. al. (eds) (Brill Nijhoff, 2020), 96-9 (evaluating the Imo's regulation of greenhouse gas emissions as an interaction of 'epistemic communities').

Zahar, supra n. 12, 182 .

UNFCCC, Report of the Conference of the Parties Serving as the Meeting of the Parties to the Paris Agreement on the Third Part of its First Session, Held in Katowice from 2 to 15 December 2018, UN Doc. CCC/PA/CMA/2018/3/Add.2 (19 March 2019), 38.

Paris Agreement, Art. 14; see Zahar, supra n. 12, 186 (discussing the potential role of the Global Stocktake as an individuation forum).

Mayer, supra n. 17, 252, 272.

Ibid., 271-2; see Taiwan, Environmental Protection Administration, 'Taiwan Shares Expertise at UNFCCC COP25,'<www.epa.gov.tw/eng/F7AB26oo7B8FE8DF/be69137e-dd1o-4910-83b8$5^{\mathrm{f} 2 \mathrm{a}} \mathrm{bc} 8 \mathrm{~b} 79 \mathrm{c}>$.

Mayer, supra n. 17, 272. 
In addition to furthering progress toward the collective aim of limiting global warming, interpreting international organizations' climate policies as unilateral declarations using the test applied to the IMO's 2018 Strategy could have positivist consequences for international law. International climate law is notoriously fragmented, and international organizations are increasingly adopting policies to mitigate climate change through their operations and matters under their jurisdiction. ${ }^{196}$ 'Legalizing' such commitments by evaluating them as unilateral declarations would treat international organizations for what they are - subjects of international law with a capacity to bind themselves. As shown in this article, the fully developed test for unilateral declarations by states can be readily analogized to international organizations. Thus, applying the approach used here could promote a constitutional framework for international law, enhancing its legitimacy and encouraging decision makers within organizations to act with a 'constitutional mindset.'197

Because international organizations are not generally subject to third-party dispute-resolution mechanisms, the practical relevance of obligations they bear differs from those held by states. ${ }^{198}$ But that does not necessarily lessen their importance. ${ }^{199}$ Viewing climate commitments as non-binding pledges rather than as legal obligations could have advantages; as scholars have pointed out, 'soft law' or political pledges can give legal-regime participants

196 See, generally, van Asselt, supra n. 18; and see, e.g., UN Environment Program, 'Leading International Organizations Commit to Climate Action', 12 December 2018, <www.unep. org/news-and-stories/press-release/leading-international-organizations-commit-climateaction>; World Bank Group, World Bank Group Climate Change Action Plan 2021-2025: Supporting Green, Resilient, and Inclusive Development (World Bank, 2021).

197 Ellis, supra n. 19, 317 (discussing the rule-creation process as a factor in the designation of international norms as law); Klabbers, supra n. 11, 316-17 (discussing constitutionalism and international organizations); Martti Koskenniemi, 'Constitutionalism as a Mindset: Reflections on Kantian Themes about International Law and Globalization', 8 Theoretical Inquiries in Law 9 (2007) (constitutional thinking can influence decision-making within international organizations).

198 Kenneth W. Abbott et al., 'The Concept of Legalization', 54(3) International Organization 401 (2000), 415 (a dimension of legalization of international commitments is the extent of delegation of interpretation and enforcement authority to third parties).

199 Kristina Daugirdas, 'Reputation and Responsibility of International Organizations', 25(4) European Journal of International Law 991 (2014), 992 (the law of international responsibility can hold organizations to account by shaping discourse about the legality of their conduct); see also Kristina Daugirdas, 'Reputation as a Disciplinarian of International Organizations', 113(2) American Journal of International Law 221 (2019) (analysing shortcomings of reputational concerns). 
flexibility and encourage greater buy-in. ${ }^{200}$ But where, as here, an organization commits to contributing to the Paris Agreement's global warming limitation goals through specific action, treating that commitment as a legal obligation brings the organization within the Agreement's relatively flexible and broad rubric. Thus, the legalization of climate commitments—at least those similar to the IMO's-maintains international organizations' autonomy while indirectly benefiting the Paris Agreement's parties and furthering its goals through the individuation process discussed above.

One might argue that, notwithstanding any normative value of viewing the IMO's 2018 Strategy as imposing an erga omnes obligation, it instead should be classified as a mere political statement, or as an organizational rule applying only between the IMO and its members, which can be withdrawn at the IMO's discretion. After all, no court has yet found that an international organization has unilaterally imposed upon itself a binding undertaking. Neither, however, has international case law or jurisprudence closed the door on international organizations' ability to do so. As AG Sharpston illustrated in her opinion in the Venezuelan Fisheries case, and as Kassoti and other scholars have argued, there are good reasons to hold organizations to their declarations if made by a competent body in language revealing a clear and specific intent to be bound in light of all the circumstances.

Under that test, the 2018 Strategy would qualify as a unilateral declaration creating an erga omnes obligation. The IMO is a powerful international organization with a broad mandate to regulate greenhouse gas emissions from shipping; and it has a procedural obligation under its constituent treaty and MARPOL to act as a forum for its members to enact such regulations. With the Strategy, the Imo declared that it would mitigate climate change from shipping in order to meet the Paris Agreement's global warming limitation goals and further its collective purposes, and it set out the means it would use to do, as well as a specific time frame. The IMO acted in response to pressure from the European Union and with the hope that the Strategy would deter other unilateral regulation from intruding into its area of responsibility.

$200 \quad$ Kenneth W. Abbott and Duncan Snidal, 'Hard and Soft Law in International Governance', 54(3) International Organization 421 (2000), 445; but see Kal Raustiala, 'Form and Substance in International Agreements', 99(3) American Journal of International Law 581 (2005), 587-8 (critiquing the soft law/hard law categorization); d'Aspremont, supra $\mathrm{n} .8$ at 128 (same); Ellis, supra n. 19. 
Viewing the Strategy as imposing an international legal obligation is not only interpretatively correct but would draw the IMO into the climate regime as a de-facto party to the Paris Agreement and thus bridge a notoriously fragmented divide between the maritime and climate legal frameworks. Doing so could also serve as a model for other international organizations as they increasingly align their activities with the Paris Agreement. Taking international organizations at their word when they make climate commitments in binding form could therefore serve the interests of both climate law and international law's evolving constitutional framework. 